Годишьак Филозофског факултета у Новом Саду, Кюига ХХХІХ-2 (2014)

Annual Review of the Faculty of Philosophy, Novi Sad, Volume XXXIX-2 (2014)

Adam Svetlik

Filozofski fakultet Univerziteta u Novom Sadu

UDK 821.162.4.09 Harpanj M.

Originalan naučni rad

\title{
LITERÁRNOKRITICKÝ OBRAT MICHALA HARPÁŇA ${ }^{1}$
}

Vo svojich literárnokritických začiatkoch polovicou 60. rokov minulého storočia Michal Harpáň bol orientovaný na srbský literárny kontext, predovšetkým na srbskú poéziu. Do slovenskej literatúry „vstúpil“" krátkymi lyrizovanými poviedkami a len neskôr, koncom 60. rokov minulého storočia začal písat' aj literárnokritické texty v slovenčine. Zo začiaktu bol jeho literárnokritický výraz výrazne esejisticky koncipovaný, no po oboznámení sa so súdobou slovenskou literárnou vedou Harpáñ svoje interpretácie literárnych textov uskutočnňuje pod výrazným vplyvom scientistických literárnovedných metodológií, predovšetkým štrukturalizmu. Tento obrat v literárnokritickej tvorbe Michala Harpáňa sa odohral začiatkom 70. rokov minulého storočia a mal d’alekosiahle následky nielen pre slovenskú vojvodinskú literárnu kritiku, ale i celkovú literatúru.

Kl'účové slová: literárna kritika, srbský literárny kontext, slovenský literárny kontext, esejistická kritika, literárnokritický obrat, literárna veda, štrukturalizmus.

Na rozdiel od väčšiny začínajúcich spisovatel’ov, ale i mnohých literánych kritikov, ktorí do literatúry najčastejšie vstupovali básnickou tvorbou, Michal Harpáň do slovenskej literatúry vkročil prózou, no prózou výrazne poetizovanou a lyrizovanou, nie vel'mi sa odlišujúcou od poézie. Štyri prózy, Oči, Rúbaniská, Chrám slnka a Temná hat', ktoré Harpáň uverejnil v rokoch 1964, 1965 a 1966 v Novom živote, súdobá slovenská vojvodinská literárna verejenost', najmä literárna kritika, prijala ako slubný a pritom v kontexte vtedy dominujúceho realistického ruralizmu, i osviežujúci začiatok mladého autora, pokračujúceho v modernizačných stopách lyrizovaných próz Jána Labátha, ktoré tento spisovatel' publikoval roku $1963 \mathrm{v}$ knihe Jazdec z Turkménska. O poetickej senzibilite mladého začiatočníka, vtedy študenta na Katedre juhoslovanských literatúr Filozofickej fakulty v Novom Sade, svedčia však aj jeho prvé literárnokritické texty písané najprv v srbčine a neskôr i v slovenčine, zamerané vo väčšine na interpretáciu poézie a napísané pritom výrazne esejistickopoetizujúcim štýlom. Dokladom pre túto Harpáňovu evidentnú začiatočnú rozkolísanost' medzi beletristickou a literárnokritickou tvorbou môže byt' napríklad i jeden z jeho prvých po slovensky publikovaných textov, esej velavravného pomenovania $O$ vztahu mladých k básňam, uverejnený roku 1965 v týždenníku Hlas l’udu, v ktorom tento, vtedy dvadsatročný literárny snaživec vel'mi zápalisto, poetickým a vznešeným štýlom propaguje poéziu a pritom vyzdvihuje jej význam v živote mladých l’udí. Aj vo svojich prvých

svetlika@ptt.rs

Rad je nastao o okviru republičkog projekta (br. 178017) Diskursi manjinskih jezika, književnosti i kultura u jugoistočnoj i srednjoj Evropi. 
literárnokritických textoch, hlavne v recenziách uverejňovaných jednak v srbských, jednak v slovenských literárnych časopisoch (Polja, Letopis Matice srpske, Index, Nový život, Hlas l'udu...) Michal Harpáň bol očividne orientovaný predovšetkým na poéziu, ktorou sa oduševňuje a ku ktorej prejavuje priam zbožnú úctu. Tak napríklad v recenzii Letopisa Matice srpske publikovanej v roku 1965 v Novom živote, Harpán̆ interpretuje do tohto časopisu zaradené básne Very Blagojevićovej, no pritom vlastne piše aj svojráznu ódu na literatúru, poéziu: ,... a jej básnický tok má svoj žlab, vieru, že nie sú iba -ó tempora! - časy technických rozletov a zábavnej hudby, ale i časy poézie; verí, že sa niekto zamilovat môže do jej básní. A od toho krajšie nič ani nie je... ". (Harpáň, 1965, 273)

Ak odhliadneme od zjavnej rétoriky, na momenty až pózy mladého, precitliveného a do poézie či literatúry priam zamilovaného autora začiatočníka, ktorý monumentalizuje a zároveň i hedonisticky vychutnáva nielen objekt svojej zamilovanosti, ale aj lásku samu, potom je v takomto Harpáňovom zápalistom prejave už predsa viditel'né aj cielavedomé úsilie ambiciózneho literárneho kritika, ktorý poéziu nevníma len ako vlastnú citovú sublimáciu či kompenzáciu, čo je príznačné pre väčšinu začínajúcich literátov, ale predovšetkým ju vníma ako najvyšší prejav duchovného života človeka, naplno podmieňujúci jeho existenciu. $Z$ dnešného pät'desiatročného odstupu už spol'ahlivo možno tvrdit', že práve takáto viera v silu literatúry a umenia bola tou základnou tvorivou vzpruhou tohto autora, ktorá poznačila nielen najväčšiu čast' jeho bohatej literárnovednej tvorby, ale podstatne určovala a podnecovala aj celkový polstoročný literárny život vojvodinských Slovákov, v ktorom Harpáňova tvorba zaberala, a mienim, že ešte stále zaberá, dominantné miesto.

Túto vlastnú tvorivú rozkolísanost' medzi beletriou a literárnou kritikou či literárnou vedou Michal Harpáň v druhej polovici 60. rokov minulého storočia prekonal jednoznačnou orientáciou na literárnokritickú tvorbu. Dôvody tomu možno hladat' predovšetkým $\mathrm{v}$ autorovej tvorivej povahe ${ }^{2}$, ale iste nie menej dôležité tu bolo i jeho štúdium juhoslovanských literatúr na Filozofickej fakulte v Novom Sade, kde sa ako študent mohol dôkladne oboznámit' nielen s juhoslovanskými literatúrami, ale tiež i so súdobou juhoslovanskou literárnou vedou, čoho dôsledky vidno predovšetkým v značnom počte Harpáňových uverejnených literárnokritických príspevkov, najmä recenzií a článkov, v srbských literárnych časopisoch. Pritom i jeho začiatok pôsobenia na Katedre slovenského jazyka a literatúry Filozofickej fakulty v Novom Sade roku 1969 na pracovnom mieste asistenta pre slovenskú literatúru, teda jeho profesionálna orientácia na pedagogickú a literárnovednú činnost', no najmä jeho postupné spoznávanie súdobej slovenskej literatúry a literárnej vedy, celý tento proces tvorivého odklonu od prózy k literárnej kritike respektíve literárnej vede zrejme len urýchlil a definitívne potvrdil.

Súbežne s touto začiatočnou ambivalenciou medzi beletristickou a literárnokritickou tvorbou, Michal Harpáň zápasil aj s d’alšou závažnou tvorivou dilemou, spôsobenou jeho pozíciou „medzi dvoma ohňami“: medzi srbskou, respektíve juhoslovanskou literatúrou, z ktorej svojím školením vychádzal a slovenskou literatúrou, kde svojim materinským

Takéto Harpáňovo tvorivé „obrátenie“ Milan Šútovec v úvode k výberu z Harpáňovej literárnokritickej tvorby Texty a kontexty privádza do súvisu aj s údajným luteránskym pragmatizmom: „,Možno u neho $v$ tom novosadskom liberálnom multietnickom prostredí iba prevládlo čosi, čo sa, či už právom alebo neprávom, v každom prípade tak trochu mytologicky prisudzuje luteránom: totiž akási vraj vyvinutejšia racionalita, akýsi vraj sklon k presnejšiemu a dôkladnejšiemu videniu a posudzovaniu vecí, akýsi vraj sklon k analytickosti, exaktnosti a pojmovému uchopovaniu predmetov záujmu. “(Šútovec, 2004, 7) 
jazykom patril, a do ktorej sa svojou prozaickou a literárnokritickou tvorbou postupne, v druhej polovici 60. rokov minulého storčia, začal i včleňovat'. Evidnenté je, že sa aj tento autor, ako naostatok aj väčšina slovenských vojvodinských literátov, ${ }^{3}$ na začiatku svojej tvorby ocitol $\mathrm{v}$ typickej bilingválnej či biliterárnej pozícii autora pôsobiaceho $\mathrm{v}$ enklávnej spoločnosti, ktorý sa musí vyporiadat' so svojou „dvojitou“ tvorivou pozíciou. Bolo teda celkom prirodzené, že sa aj Michal Harpáň, žiak novosadského srbského gymnázia a neskôr študent Katedry juhoslovanských literatúr, prvotne orientoval na srbský, či vtedy ešte stále aktuálny juhoslovanský literárny kontext, ktorý zrejme dobre poznal a zo začiatku ho i naplno pocitoval ako svoj vlastný. Explicitným dokladom tohto tvrdenia môže byt' napríklad jeho štúdia o poézii významného srbského básnika Miodraga Pavlovića, v ktorej sa Michal Harpáň o srbskej poézii zmieňuje ako o „našej“, teda ako o vlastnej: „Ali Miodraga Pavlovića su funkcionalnoj upotrebi reči najviše učili engleski pesnici Eliotovog tipa. - U našoj poeziji nameće se primer Momčila Nastasijevića." (Harpanj, 1972, 8). O takomto Harpáňovom postoji k srbskej literárnej tradícii svedčí i celý rad jeho literárnokritických článkov, recenzií a štúdií, uverejnených v srbských literárnych časopisoch, v ktorých vel'mi zručne interpretuje texty srbských autorov, najmä básnikov, a pritom zasvätene píše i o celkovom stave súdobej srbskej literatúry, začleňujúc sa tak jednoznačne do srbského literárneho kontextu, predovšetkým do srbskej literárnej kritiky. Vyrcholením takejto Harpáňovej tvorivej orientácie je jeho prvá publikovaná kniha literárnych kritík Izmedju dve vatre (1972), ktorú vydala Matica srpska v Novom Sade $\mathrm{v}$ edícii Biblioteka prva knjiga, do ktorej autor zaradil hlavne svoje v srbčine napísané literárnokritické texty o niektorých významných srbských spisovatel'och a kritikoch: Miodragovi Pavlovićovi, Vaskovi Popovi, Brankovi Miljkovićovi, Novici Petkovićovi a Boškovi Ivkovovi. ${ }^{5}$

Na takúto Harpáňovu prvotnú orientáciu na srbský literárny kontext, okrem školenia zrejme prajne vplývala aj relatívna vyspelost' srbskej literatúry, ktorá sa v porovnaní so slovenskou literatúrou prakticky o celé desat'ročie skôr, teda už v 50. rokoch 20. storočia, zbavila ideológiou nanucovanej tvorivej metódy socialistického realizmu (no pritom nie celkom i ideológie), a neskôr už vcelku úspešne sledovala, a zároveň sa i zapájala do súdobých svetových literárnych tendencií. $\mathrm{Na}$ druhej strane v slovenskej literatúre sa

3 Väčšina slovenských vojvodinských autorov sa v jednom svojom tvorivom období, najčastejšie to bolo začiatočné, pokúsila zapojit' aj do väčšinového (juhoslovenského, srbského, vojvodinského...) literárneho kontetxtu, bud' úplnou preorientáciou na nový jazyk a samým tým aj literárny kontext a literárnu tradíciu, alebo len súbežným písaním v dvoch jazykoch. Najvýraznejšie sa to udilao u Vítazoslava Hronca a Zlatka Benku, no biliterárnost' stretávame aj u Pal'a Bohuša, Viere Benkovej, Martina Prebudilu... Možno však konštatovat', že sa sa všetky tieto biliterárne „,výlety“ spravidla rýchlo skončili návratom k vlastnému literárnemu kontetxtu, teda k tvorbe $\mathrm{v}$ materinskom jazyku.

4 O takomto Harpáňovom vzt’ahu k srbskej literatúre hovorí i svedectvo z prvej ruky je Milana Š́tovca, ktorý v spomínanom úvode v Harpáňovej knihe Texty a kontexty píše: „Niekol’ko dní pred Vianocami roku 1966 sme boli spolu s Pavlom Vilikovským ako vtedajši redaktori Slovenských pohl'adov po prvý raz na slúžobnej ceste v redakcii Letopisu Matice srpske v Novom Sade. Našimi hostitel'mi boli redaktori a spisovatelia Aleksandar Tišma a Boško Petrović. Tí nám tam kdesi na chodníku v strede mesta hned prvý den̆ pobytu predstavili mladého študenta ,juhoslovanskej literatúry“ Mihajla Harpanja, ktorý im do Letopisu začinal písat' recenzie a ktorého pokladali za nádejného „, srbského literárneho kritika“. (Šutovec: 2004, s.7) Treba však toto trvdenie upresnit’: sám autor sa vtedy cítil skôr ako juhoslovanský, a nie srbský literárny kritik...

5 Zo slovenských autorov Harpáň v tejto knihe píše predovšetkým o svojom generačnom vrstovníkovi Vít’azoslavovi Hroncovi, ktorému venuje dve literárnokritické štúdie, potom o Michalovi Babinkovi, ale i o slovenských básnikoch Jánovi Ondrušovi, Milanovi Rúfusovi a Jánovi Stachovi. 
prakticky len v druhej polovici 60. rokov minulého storočia začal výraznejší proces liberalizácie, pluralizácie a otvárania sa literatúry voči svetových literárných dianí. Tento proces bol síce už začiatkom 70. rokov spomalený ideologickým pokusom o tzv. normalizáciu a konsolidáciu slovenskej literatúry, no vtedy už bolo celkom jasné, že sa zastavit' nemohol. Trvalo to až do roku 1989, ked' padol totalitný režím v Československu a ked' sa slovenská literatúra aj definitívne zbavila ideologického nátlaku. V takomto kontexte odpozorované potom aj svojrázny zlom a definitávna (pre)orientácia na slovenský literárny kontext, ktorý sa u Michala Harpáňa odohral práve koncom 60. rokov minulého storočia, treba pozerat' ako prajné pôsobenie liberalizácie v slovenskej literatúre toho obdobia. Na základe Harpáňových uverejnených literánokritických textov, hlavne štúdií a recenzii v časopise Nový život v druhej polovici 60. rokov 20. storočia, evidentné je, že mladého literárneho kritika silne zaintrigovala pozmenená situácia v slovenskej literatúre, predovšetkým nástup mladých básnických a prozaických generácií, ktoré sa usilovali modernizovat' slovenskú literatúru a na ten spôsob ju zapojit' do súdobých svetových literánych tendencií. To, že v tom období Harpáň už intenzívne číta a analyzuje súčasnú slovenskú literatúru vidno napríklad v jeho recenzii Pol kroka, krôčik uverejnej roku 1967 v Novom živote, v ktorej sa príliš kriticky, no pritom i z pozície dobrého znalca súčasnej slovenskej poézie, zmieňuje o v srbčine publikovanej antológii slovenskej lúbostnej poézie Bratislavsko proleće. A vidno to tiež i v jeho recenzii z roku 1968 pomenovanej Hlas nepokoja a hladania a uverejnenej v Novom živote, v ktorej dôkladne interpretuje druhý román Rudolfa Slobodu Britva, no v ktorej sa zároveň znalecky zmieňuje aj o niektorých iných prózach vtedy mladých slovenských prozaikoch (Ladislav Ťažký, Vincent Šikula, Peter Jaroš, Ján Johanides...).

Svojráznym prechodom Michala Harpáňa od srbského k slovenskému literárnemu kontextu, teda aj „,prestúpenie“ zo srbskej do slovenskej literárnej kritiky, je jeho porovnávacia štúdia Preventívna básnická akcia - na okraj poetík Vaska Popu a Jána Ondruša, uverejnená roku 1971 v Novom živote (Harpáň, 1971), publikovaná tiež aj v Letopise Matice srpske, Slovenských pohladoch a zaradená i do knihy Izmedju dve vatre. Je to iste jedna z Harpáňových najdôležitejších literárnokritických štúdií, kde sa prejavil nielen ako výnimočný odborník pre poéziu dvoch možno i najvýznamnejších básnikov srbskej a slovenskej poézie 20. storočia, ale kde tiež jednoznačne naznačil aj úsilie inovovat' a menit' vlastnú literárnokritickú metódu smerom k premyslenej a systematickej intepretácie samotného literárneho textu ( ,...môj záujem od začiatku bol a zostáva iba $v$ doméne básnického zjavu ako takého, v doméne imanentnej poetiky...")

Harpáňov zvýšený záujem o slovenskú literatúru vznikajúcu na Slovensku prebiehal súbežne s jeho intenzívnym a sústavným čítaním a intepretovaním slovenskej vojvodinskej literatúry, o ktorej však mal, podobne ako aj jeho vrstovník Vít’azoslav Hronec, vel'mi kritickú mienku. Tento jeho záujem o slovenskú vojvodinskú literatúru však nepretržite stúpal, takže už v roku 1967 na literárnej porade tento, vtedy sotva dvadsattri ročný začínajúci literárny kritik prečítal úvodný, čo vtedy prakticky znamenalo i smerodajný referát ambiciózne pomenovaný Problémy našej prozaickej tvorby ${ }^{6}$. Tento Harpáñov

Bol to svojrázny úvod k jeho rozsiahlejšej syntetizujúcej štúdii $O$ našej súčasnej prozaickej tvorbe, prečítanej tiež ako úvodný referát na literárnej porade roku 1969 a neskoršie uverejnenej i v Slovenských pohl'adoch, ale aj príprava pre celý rad rozborov súčasnej vojvodinskej prózy (Poznámky o próze juhoslovanských Slovákov, Podoby a premeny narácie...), zhrnutých hodne neskoršie v literárnohistorickej monografii Premeny rozprávania (1990). 
úvodník pre poradu sa však už nevyznačoval popisno-rétorickým štýlom, aký vtedy dominoval v slovenskej vojvodinskej literárnej kritike, ale ciel'avedomou zameranostou na interpretáciu samotného literárneho textu, predovšetkým vtedajšej rozbiehajúcej sa prozaickej tvorby vojvodinských Slovákov a vyznačoval sa pritom aj výrazne kritickým, nekompromisným a nealibistickým postojom, v ktorom sa slovenská vojvodinská literatúra hodnotí v širších literárnych kontextoch? ${ }^{7}$ teda bez nárokov na nejakú „menšinovú zl’avu“. Podobne koncipovaný príspevok, lenže o súdobej básnickej tvorbe vojvodinských Slovákov, mal i Vít’azoslav Hronec, takže táto porada bola svojráznym nástupom mladej generácie, ktorá, teraz to už spol’ahlivo môžeme tvrdit', podstatne zmenila, predovšetkým zmodernizovala slovenskú vojvodinskú literatúru. ${ }^{8}$

V tomto kontexte odpozorované, velavravné je však i to, že Harpáňov postoj $\mathrm{k}$ niektorým mladším spisovatelom, predovšetkým k modernistickej básnickej tvorbe Vítazoslava Hronca, už nebol taký kritický, ale skôr empatický, čo jasne vidiet' z jeho eseje Medzi dvoma ohn̆ami, uverejnej roku 1969 v Novom živote a zaradenej neskôr i do knihy Izmedju dve vatre 9 . Z dnešnej perspektívy odpozorované vidno, že práve táto Harpáňova esej, ktorá sa stala v značnej miere smerodajnou pre všetky neskoršie interpretácie Hroncovej poézie, bola svojráznou kulmináciou Harpáňovho prvého, podmienečne povedané esejistického tvorivého obdobia, a že sa začiatkom 70. rokov 20. storočia jeho literárnokritický prejav začal podstatnejšie menit', predovšetkým ,scientizovat'“.

Avšak v druhej polovici 60. rokov 20. storočia je Michal Harpáň ešte stále pod značným vplývom vtedajšej srbskej literárnej kritiky ${ }^{10}$, čo je celkom pochopitel'né, ak máme na zreteli dominujúci, pre mladého kritika však zrejme málo podnetný uvodnikovo-referátový, v podstate pozitivisticko-impresionistický literárnokritický diskurz slovenskej vojvodinskej literarnej kritiky ${ }^{11}$ a zároveň jeho ešte stále nedostatočnú informovanost' o dianiach v literárnej kritike a vede na Slovensku. Jedinou výnimkou, ktorá vlastne potvrdzovala takúto nepodnetnost' slovenskej vojvodinskej literárnej kritiky toho obdobia bol Labáthov výrazne štrukturalisticky koncipovaný rozbor poézie Viery Benkovej pomenovaný $O$ najnovších básňach Viery Benkovej-Popitovej a uverejnený roku 1965 v Novom živote. Zaujímavé je však, že sám Harpáň tento Labáthov priekopnícky text v literárnej kritike vojvodinských

\footnotetext{
Vel’avravné je v tomto ohl'ade autorovo vyznaie: „Nemôžem súdit’ o úrovni súčasnej prózy na Slovensku, tú problematiku nepoznám dostatočne, aby som robit'nejaké analógie. No. ked'sa naša poviedka porovná so súčasnou juhoslovanskou, priznávam, že ma výsledok neuspokojuje: súčasná juhoslovenská poviedka je umelecky hodne vyspelejšia ako naša. " (Harpáň, 1967, 37)

8 Význam týchto príspevkov ilustruje Hroncov denníkový záznam: „Až teraz sa mi totiž v hlave začína rozjasnievat’ to, čo mi inštinkt a cit už dávnejšie navrávajú: že Harpán̆ a ja sme generačný druhovia a že teda musíme fúkat' do tohto istého vreca. Čo na tom, že sa takmer nepoznáme! Dôležitejšia je predsa skutočnost', že vychádzame z literatúry, ktorá je ovela vyspelejšia než táto naša menšinová a že zastupujeme rovnaký estetický koncept tvorby. A táto porada je dobrou príležitostou efektne to demonštrovat' pred potuchnutými tvárami našej literárnej smotanky. Netreba ich síce vylakat', len dat' na vedomie, že takto to d'alej už vari nepojde. " (Lutrov, 2003, 19)

9 Za túto esej Harpáň získal i Cenu Nového života.

10 Nie náhodou mu preto i Samuel Čeman v texte Originálna literárna kritika a iné príspevky, uverejnenom roku 1966 v prvom čísle Nového života vytýka „draškoredjepovské“ a „boškonovakovićovské“ kompilácie v literárnokritickom prehovore.

11 O aký tu problém išlo, možno najlepšie ilustrujú Kmetove dilemy pri interpretovaní, či „čítaní“ Babinkovej poézie: ,Ale háčik je v tom, ako Babinku čitat' a vnímat'? Či obrátit’ knihu naopak, či prižmúrit’ a zúzitt si zrenice pritom, alebo si vypit' vopred glg ostrého, aby si sa lepšie stotožnil s autorom? A kedy ju čitat? Pri únave po práci ona neblaži dušu, po dobrom obede nechutná a pred spaním neuspáva... “(Kmet', 1965, 306)
} 
Slovákov vnímal v čase ked' bol uverejnený vcelku negatívne, takže ho vo svojom texte $O$ poézii Viery Benkovej a o kritike jej poézie u nás, odmietol ako lingvistický, teda neadekvátny a pre literárnu kritiku nepostačujúcí: ,Čitatel', ked' prečita Labáthovu štúdiu, bude zoznámeni so štruktúrou verša Viery Benkovej, so sémantickými vlastnostiami poézie, ale nie aj s podstatou básní, s tým čo ony znamenajú ako celky.....) Štrukturalistickú metódu kritiky nijako nemôžem prijat', lebo $v$ nej nevidím state, $v$ ktorých by ona bola sprostredkovatel'om medzi čitatel’om a dielom, o ktorom píše.". (Harpáň, 1966, 138) Avšak už o dva roky neskoršie, v texte Básnické relácie Michala Babinku Harpáň apeluje za nový prístup k interpretácii Babinkovej modernistickej poézie: „Domnievam sa preto, že by bolo zaujímavé urobit'štrukturalistickú analýzu, ani nie natol'ko samotných básní Michala Babinku, nakol'ko jeho tvorivého procesu." (Harpáň, 1968, 152). Toto svoje vtedajšie predsavzatie Harpáň aj úspešne realizoval, ponajprv v niekol'kých „prípravných“ parciálnych rozboroch Babinkovej poézie uverejnených $\mathrm{v} 70$. rokoch minulého storočia $\mathrm{v}$ Novom živote (Nadrealistická metafora Michala Babinku, Interpretácia básne Michala Babinku Hlasujem za hriech I a Sémantická podmienenost' pevnej básnickej formy) a neskoršie aj komplexne, $\mathrm{v}$ jednom z najvýznamnejších a priekopníckych diel v literatúre vojvodinských Slovákov, v typicko štrukturalistickej monografii Poézia a poetika Michala Babinku (1980).

Harpáňov inovačný prínos do slovenskej vojvodinskej literárnej kritiky sa však v tomto jeho prvom tvorivom období prejavoval predovšetkým v literárnokritickej zameranosti na samotný literárny text, na jeho imanentnost', literánost', teda v jeho úsilí o premyslenú, dôkladnú a systematickú interpretáciu všetkych rovín literárného diela, ktorá by pritom neuprednostňovala tematicko-motivickú a sémantickú rovinu pred rovinou výrazovou, čo bola zjavná tendencia vo vtedajšej literárnej kritike vojvodinských Slovákov ${ }^{12}$, ale by sa zamerala na všetky roviny literárneho textu a najmä na ich vzájomnú prepojenost'. Dôležitá bola i Harpáňova sústavná kontextualizácia interpretovaného literárneho textu, $\mathrm{v}$ ktorej prišla do výrazu nielen jeho erudovanost' a zorientovanost' $\mathrm{v}$ širších literárnych kontextoch, najmä v juhoslovanskom a európskom, ale aj jeho presné hodnotiace kritéria, stanovené na podkladoch prísnych univerzálnych literárnych hodnôt. Zjavná esejistickost', na momenty až svojrázny slovný a významový exibicionizmus, sprevádzaný pritom najčastejšie i výraznou patetickostou týchto prvých Harpáňovych literárnokritických textov, postupne však vystriedala kritikova sústredenost' na objektívnu, pritom výrazovo strohejšiu, striedmejšiu a terminologický dôslednejšiu interpretáciu samotného textu.

Významnú úlohu v týchto posunoch v literárnokritickom prejave Michala Harpáňa odhohral aj jeho „objav“ československej literánej vedy ${ }^{13}$, ktorá sa v 60. rokoch 20. storočia

12 Jedna z prvých polemík v literatúre vojvodidnských Slovákov, ktorá sa začiatkom 60. rokov minulého storočia viedla medzi Jánom Kmet’om a Michalom Babinkom bola zameraná okrem iného aj na otázku vzt’ahu medzi obsahom a formou, kde Kmet' údajnú nezrozumitel'nost' Bainkových básní vysvetl'oval básnikovým dôrazom na výrazovej rovine básnického prehovoru a pritom sa sám zasadzoval za primát obsahu pred formou...

13 V tomto kontexte bol zrejme dôležitý najmä jeho osobný priatel'ský vzt’ah s vtedy mladým slovenským literárnym vedcom Milanom Šútovcom, ktorý podl’a vlastného vyznania, Harpáňovi pri svojich návštevách Novému Sadu prinášal najnovšie vydania československej literánej vedy. Pritom aj sám Harpáň, ktorý vtedy začal častejšie cestovat’ na Slovensko, z tychto svojich návštev si prinášal knihy súčasných slovenských spisovatel'ov a literárnych vedcov, takže sa podl'a slov Milana Š́tovca postupne ,...z neho stal literárny vedec dobre vyškolený na tých najlepšich tradíciách slovenského a českého literárnovedného myslenia." (Š́tovec: 2004, s. 8) 
znovu začala intenzívne rozvíjat', ponajprv tak, že sa „objavovali“ dielá, teórie a postuláty ruského formalizmu a československého štrukturalizmu, predovšetkým výskumy Jana Mukarovského, ale neskôr aj zintenzívnením vlastných, originálnych literárnovedných výskumov, sústredených hlavne v Kabinéte literárnej komunikácie a experimentálnych metodík v Nitre. Vel'avravný je v tomto kontexte i fakt, že ked' bol roku 1974 zvolený za hlavného redaktora časopisu Nový život, Harpáňov prvý väčší redaktorský projekt bol uverejnenie cyklu literárnovedných štúdií najvýznamnejších súdobých slovenských literárnych vedcov (František Miko, Mikuláš Bakoš, Ján Števček, Stanislav Šmatlák, Anton Popovič, Dionýz Durišin), sprevádzaný pritom jeho dôkladnou a zasvätenou analýzou literárnovedných diel a teórií týchto autorov. V týchto textoch Michal Harpáň už s neskrývaným oduševnením píše o súdobých literárnovedných výskumoch a tendenciách v slovenskej literárnej vede, pričom zároveň aj sám vo vlastnej literárnekritickej tvorbe začína uplatňovat' niektoré z týchto postulátov a literárnovedných termínov, predovšetkým vtedy nanajvýš aktuálnu a dôkladne rozpracovanú výrazovú sústavu Františeka Mika. Z takejto perspektívy odpozorované preto ani neprekvapuje, že sa o svojom predošlom, „nevedeckom“ literárnokritickom tvorivom období Harpáň zmieňuje príliš samokritický: „Teoretické súvislosti našej literatúry sme budovali na sociologických a iných literatúre nevlastných otázkách a teoretické odkazy samej litearatúry sme slabo počuli a nedostatočne akceptovali. (Harpáň, 1974, 487). Avšak Harpáň nebol len samokritický, ale bol aj príliš kritický voči celkovému stavu súdobej slovenskej vojvodinskej literárnej kritiky, o čom dôkladne píše v prehladnej štúdii Súradnice našej literárnej kritiky (Harpáñ, 1977). V týchto svojráznych dejinách slovenskej vojvodinskej literárnej kritiky Harpáň podčiarkuje predovšetkým „,nedostatočnú vnútornú konsolidáciu a najmä hierachizáciu postupov“, potom aj tzv. „prívlastkové hodnotenie“, ale najmä nedostatočnú odbornost' literárneho kritika, čiže „,samoukost”, pričom od slovenských vojvodinských literárnych kritikov očakáva , viacej rozhladenosti v terminologických a metodologických otázkach súčasnej teórie literatúry“, no nie i strnulosti, lebo je podla neho ,aj pri metodologicky prísne stanovenom rozbore žiadúca invencia a intuícia, pritomné aj vo vedách exaktnejšich od literárnej vedy, predmetom ktorej je básnické slovo, vymkýnajúce sa z každej definície."

Aký obrat v slovenskej literárnej kritike spôsobila literárnokritická činnost' Michala Harpáña signalizuje úž v podstate negatívna recenzia Jána Kmet’a Harpáňovej prvej po slovensky publikovanej knihy literárnych kritík Priestory imaginácie (1974). Ján Kmet', vtedajšia iste najväčšia literárna autorita vojvodinských Slovákov v recenzii pomenovanej Harpáňove priestory imaginácie (Kmet', 1975) mladému literárnemu kritikovi zazlieva, okrem iného to, ,že sa príliš dal viest' inými“", a že sa „,bráni i tomu, v čom sa veri'“, mysliac pritom hlavne na Harpaňov kritický postoj voči sociologizmu a biografizmu v literárnej kritike, ktoré aj on sám, teda Ján Kmet', vo svojej literárnokritickej tvorbe uplatňoval. Avšak takúto Kmet'ovu reakciu možno pozerat' aj v širšom kontexte jeho permanentnej polemiky s Michalom Babinkom o (nezrozumitel’nosti) modernej, čiže Babinovej poézie. Práve v takom svetle treba potom vnímat' aj najzásadnejšiu Kmetovu výčitku Harpáňovi vztahujúcu sa na nekomunikatívnost' jeho literárnej kritiky: „, O tomto by sa dalo hodne hovorit' a v našich reláciách, zdá sa mi, hodne i s hladiska komunikátivnosti, čiže z hl'adiska prístupnosti našich vlastných textov našej vlastnej literánej verejnosti, ktorá má radšej jasné cesty hoci skromnejšieho prúdu nášho literárnokritického snaženia než kmitavé objavy a záblesky, ktoré prasknú a stratia sa, lebo vytrhnuté - visia, a nespustené na zem - zostávajú neuzemené." Polemicky, ale zrejme v nejednom ohlade i obranne voči 
Harpáňovi a jeho náhl'adoch na literárnu kritiku a literatúru, Kmet' vystúpoval aj neskoršie, výrazne v texte Kritika nesystematická, jubilanta neukázneného (Kmet', 1977), v ktorom okrem iného píše: ,...naša kritika sa už v koreňoch znemožňuje a podtina, ked'sa tak-ako sa to robi i v spomenutom najnovšom úvodniku - broji ptori tzv. privlastkovému hodnoteniu, $i$ ked' je to najobyčajnejší, najprirodzenejši, najludskejši a každému najzrozumitel’nejši spôsob hodnotenia v každej kritike." Na rozdiel od Harpáňa, ktorý sa v tom období už naplno usiloval o zjavnú profesionalizáciu a scientizáciu literárnej krtiky, Ján Kmet' vo svojom texte explicitne a rezolútne tvrdí, že „literárna kritika vôbec nie je vedecká aktivita“, a pritom sa jednoznačne zasadzuje za svojrázny impresionisticko-intuitívny prístup kritickom čítaní literárneho texta: ,hodnotiace poznanie $v$ tvorivom procese literárnej kritiky nijako nie inak len odrazu frkne, ako ked" preskoči iskra, teda zdeje sa okamžite, ked'že sa literárne dielo najlepšie hodnoti hned' po prvom prečitani bez akéhokolvek dodatočného prinucovania seba, ktoré je beznádejne márne, ak sa len nechce miečo vynútit,' zneprírodzenit' a znásilnit."

Aj niektorí iní slovenskí vojvodinskí spisovatelia a literárni kritici starších generácií Harpáňovu vedeckú koncepciu literárnej kritiky prijali tiež s menšími alebo väčšími výhradami, no mladšie generácie už také výhrady zrejme nemali a menej viac sa usilovali pokračovat' v stopách stanovených takýmto Harpáňovým literárnokritickým pôsobením. O význame literárnokritického pôsobenia Michala Harpáňa v kontetxte slovenskej vojvodinskej literatúry nasvedčujú aj jednoznačne pozitívne ohlasy a recenzie jeho literárnovedných kníh jednak doma (Michal Duga, Miroslav Demák, Miroslav Dudok, Vítazoslav Hronec, Viera Benková....), jednak na Slovensku (František Miko, Peter Andruška, Milan Resutík, Dalimir Hajko, Ján Števček, Peter Liba, Milan Šútovec...). Svoje náhl'ady na literárnu kritiku respektíve literárnu vedu koncipované v 70. rokoch Harpán neskôr, najmä začiatom 80. rokoch minulého storočia dôkladne rozpracoval, spresnil a explikoval najmä v štúdiách Podnetnost' novšej literárnej vedy (1982), Hodnoty a hodnotenie (1982) a Podstatné otázky literárnej vedy (1985), no definitívne ich stanovil a syntetizoval vo svojom zrejme najdôležitejšom literárnoteoretickom diele, v Teórii literatúry (1986), ktorá mala vel'ký ohlas zvlášt' na Slovensku, kde je už dlhé roky základnou literárnoteoretickou pedagogickou príručkou.

V 80. rokoch minulého storočia Harpáň pokračoval v intenzívnej literárnokritickej činnosti. Písal recenzie a články o nových knihách slovenských (vojvodinských) a srbských autoroch, napríklad Michala Dugu, Jovana Zivlaka, Františeka Mika, Milana Š́tovca, Zlatka Benku, Miroslava Ďugu, Zoroslava Speváka..., no badatel'ný je už v jeho tvorbe aj značný posun $\mathrm{k}$ syntetizujúcejším výskumom slovenskej vojvodinskej literatúry, predovšetkým k literárnohistorickým výskumom prózy vojvodinských Slovákov (Hurbanové predvojnové a medzivojnové prózy, Próza posledného desatročia a problém hodnôt, Hladanie domova, hladanie žánru, Variácie na tému: naša próza, Tušiakove poviedky v kontexte našej súčasnej prózy, Javy a znaky, Príspevok k typológii našej prózy vobdobi realizmu, Postavy a priestory Maršallových noviel, Čas Zuzky Turanovej, Śtyri pokusy premeny, Śtyria dedinský poviedkári...), z čoho potom roku 1990 vznikla jeho obsiahla literárnohistorická monografia, svojrázne dejiny slovenskej vojvodinskej prózy Premeny rozprávania (1990). Orientácia na literárnohistorický výskum v Harpáňovej tvorbe je evidentná a možno konštatovat' i dominantná, aj v posledných dvoch desat'ročiach, čo vidno už v jeho monografickej knihe O Pal'ovi Bohušovi (1999), zostavenej však vo vel'kej miere $\mathrm{z}$ recenzií jednotlivých Bohušových kníh, ale vidno to najmä $\mathrm{v}$ dlhšej 
literárnohistorickej šúdii Slovenská literatúra v Juhoslávii po roku 1945 uverejnenej roku 1995 v časopise Slovenská literatúra a taktiež aj v dvoch štúdiách o slovenskej poézii respektíve literárnej kritiky v prvej polovici 20. storočia, zaradených do najnovších Dejín slovenskej litearatúry (2009).

Okrem tohto výrazného posunu $\mathrm{k}$ literárnohistorického výskumu, pre posledné dve desatročia v tvorbe Michala Harpáňa príznačný je aj jeho zvýšený teoreticko-interpretačný záujem o literárnu tvorbu vznikajúcu v enklávnej spoločnosti. Vychádzajúc tu zrejme ponajprv z vlastnej životnej a tvorivej skúsenosti a opierajúc sa pritom aj o niektoré teoretické východiská, o tejto problematike Harpáň napísal niekol'ko pozoruhodných štúdií (Národnostné literatúry v medziliterárnom procese, Singulár a plurál slovenskej literatúry na Dolnej zemi, Osudy a perspektívy menšinovej literatúry...), v ktorých sa usiloval teoreticky rozpracovat' a zdôvodnit' tézu o trojkontextovosti literatúry vznikajúcej v enklávnych pomeroch. Súbežne s orientáciou na túto problemtikou, zvýšil sa aj jeho záujem o problém tzv. dolnozemskej lieratúry, teda o otázku blízkosti a prepojenosti tvorby Slovákov v Mad’arsku, Rumunsku a v Srbsku, o čom v tomto období napísal niekol'ko dôkladných a obsiahlých štúdií (Básnické paradigmy panonského archetypu, Slovenský dolnozemský básnici v mozaike slovenskej poézie, Typologické rozkmity slovenskej dolnozemskej literatúry, Dolnozemská básnická vetva...)

Zrejme v súlade so súčasnými postmodernými či postštrukturalistickými literárnovednými tendenciámi vo svojej literárnokritickej tvorbe v poslednom období Michal Harpáň ojedinele siahal aj po typickom esejistickom výraze, čo vidno predovšetkým v jeho esejách Pokus o juhonostalgiu, Rozlúčka s privlastkom, Fenomén(ológia) čitania, Melanchólia, Orfeus, Rilke... Evidnentné je však, že tento jeho svojrázny nostalgický návrat $\mathrm{k}$ vlastným literárnokritickým koreňom či začiatkom bol len krátkotrvajúcim výletom, a že Harpán aj v tomto období zostáva verný a dôsledný svojmu, v 70. rokoch dôkladne a pevne sformovanému literárnovednému diskurzu, pre ktorý je príznačné predovšetkým vedecké či metajazykové chápanie podstaty literárnokritickej činnosti, vyslovené ešte roku 1982 $\mathrm{v}$ texte Podnetnost' novšej literárnej vedy: „Nezriedka sa možno stretnút aj so situáciou, že sa literárna veda obrodzuje zo seba samej: literatúra jej slúži len ako materiál na výstavbu vlastného systému. To je metodologická chyba, lebo v literárnom vedcovi vždy musí byt' vedomie, že je jeho aktivita vo vzt'ahu k literatúre metajazykom. "(Harpáň, 1982a, 194) Takýto postoj zároveň naznačuje i Harpáňovu, pre literárneho kritika vel'mi dôležitú a povzbudzujúcu vieru v imanentnú, objektívnu hodnotu literárneho texta, ktorú on môže svojim výskumom dosiahnút', spoznat': ,sme mienky, že estetická hodnota literárneho diela nie je mimotextová skutočnost'. To by znamenalo, že je estetická hodnota v diele imanentne a štruktúrne pritomná..." (Harpáň, 1982b, 422)

\section{LITERATÚRA}

Harpán̆, M. (1965). Letopis Matice srpske 6,7/1965. Nový život, 3, 273-274.

Harpáň, M. (1966). O poézii Viery Benkovej a o kritike jej poézie u nás. Nový život, 1-2, 136-138.

Harpáň, M. (1967). Problémy našej prozaickej tvorby. Nový život, 1-2, 37-42.

Harpán̆, M. (1968). Básnické relácie Michala Babinku. Nový život, 2, 152- 155.

Harpáň, M. (1971). Preventívna básnická akcia - na okraj poetík Vaska Popu a Jána Ondruša. Nový život, 1, 3-15. 
Harpanj, M. (1972). Izmedju reči i stvari. U: Harpanj, M. (1972). Izmedju dve vatre. Novi Sad : Matica srpska.

Harpáň, M. (1974). Východiská poézie poézie Juhoslovanských Slovákov. Nový život, 6, 487-503.

Harpáň, M.(1977). Súradnice našej literárnej kritiky. Nový život, 1, 1-11.

Harpáň, M. (1982a). Podnetnost’ novšej literárnej vedy. Nový život, 2, 193-198.

Harpáň, M. (1982b). Hodnoty a hodnotenie. Nový život, č, 422-426.

Kmet', J. (1965). Babinkove závratné verše, Nový život, 4, 306-309.

Kmet', J. (1975) Harpáňove priestory imaginácie. Nový život, 4, 372-376.

Kmet', J. (1977). Kritika nesystematická, jubilanta neukázneného. Nový život, 3, 220-223.

Lutrov, V. (Hronec, V.) (2003). Nebo nad Helespontom. Báčsky Petrovec: Kultúra.

Sútovec, M. (2004). Na úvod. U: Harpáň, M. (2004). Texty a kontexty. Bratislava: Literárne informačné centrum.

Adam Svetlik

\section{KNJIŽEVNOKRITIČKI OBRT MIHALA HARPANJA}

\section{SAŽETAK}

U svojim književnokritičkim počecima polovinom 60. godina prošlog veka Mihal Harpanj je bio orijentisan na srpski književni kontekst, pre svega na savremenu srpsku poeziju. U slovačku književnost se uključio kratkim lirskim pripovetkama a tek kasnije, krajem 60. godina, počeo je da piše i književnokritičke textove na slovačkom jeziku. U početku je njegov književnokritički izraz bio izrazito esejistički koncipovan, no posle susreta sa savremenom slovačkom naukom o književnosti, Harpanj svoje inetrpretacije književnih tekstova realizuje pod izrazitim uticajem scientističkih književnonaučnih metodologija, pre svega strukturalizma. Ovaj obrat u književnokritičkom stvaralaštvu Mihala Harpanja se odigrao početkom 70. godina prošlog veka i imao je dalekosežne posledice ne samo za slovačku vojvodjansku književnu kritiku, nego i celokupnu književnost.

Ključne reči: književna kritika, srpski književni kontekst, slovački književni kontekst, esejistička kritika, književnokritički obrt, nauka o književnosti, strukturalizam

Adam Svetlik

\section{LITERARY CRITICAL TURN OF MICHAL HARPANY}

\section{SUMMARY}

In his literary critical beginning in mid 1960s Michal Harpany was focused on the Serbian literary context, primarily contemporary Serbian poetry. He became interested in Slovak literature through short lyrical stories and only later, at the end of the 1960s, he started writing literary critical texts in Slovak. At first, his literary critical expression was very essayistic, but after the encounter with contemporary Slovak literary science, Harpany wrote his interpretations of literary texts under a strong influence of scientific literary methodologies, primarily structuralism. This turn in the literary critical opus of Michal Harpany happened at the beginning of the 1970s and had long-term consequences, not only for Vojvodinian Slovak literary criticism, but for whole literature.

Key words: literary criticism, Serbian literary context, Slovak literary context, essayistic criticism, literary critical turn, literary science, structuralism. 